\title{
Fuelwood scarcity and forest policy on Santo Antao, Cabo Verde
}

J. van den Briel and R. Brouwer (Department of Forest Management, Agricultural University, P.O. Box 342, 6700 AH Wageningen, Netherlands)

Received 24 September 1986; accepted 3 November 1986

\begin{abstract}
A fuelwood study in Cabo Verde showed how local people are confronted with increasing shortages of fuelwood, in spite of massive reforestation. This is caused by conflicting objectives of the reforestation project, which is primarily aimed at erosion control, and by restrictive external conditions.
\end{abstract}

Key words: fuelwood situation, forest policy, erosion control, Cabo Verde.

Introduction. The Planalto Leste forestry project in Santo Antao, Cabo Verde, is situated in the central mountain region ( \pm 800-1500 meter a.s.l.) of the island. In the project area approximately $30 \%$ of the land is in use for rainfed agriculture, $48 \%$ as rangeland, $6 \%$ as forest reserve and $16 \%$ is waste land (DGIS, 1983). All the land is private property. Only $27 \%$ of the total area, however, is directly controlled by the local inhabitants. The agricultural lands are mostly managed by the owners themselves ( $42 \%$ of the households), or by tenants $(27 \%$ ), while the rangelands are in communal use. The forest lands are rented by the State. The main sources of living are animal husbandry, agriculture, and recently the employment scheme of the Planalto project. Due to severe erosion and to the persisting droughts of the last years, the people meet problems in generating a living from agriculture.

The Planalto project has been designed to improve this situation. The project takes place within the framework of the island-wide rural development strategy of the Ministry of Rural Development (MDR). The Forestry Service is part of this ministry. The main objectives of the project are:

- to combat erosion,

- to increase water infiltration,

- to increase the production of firewood and timber,

- to improve agriculture and rangeland management,

- to increase economic activity and to raise the standard of living,

- to train women and men for the local forestry service and MDR.

The main activities are erosion control, firewood production and the construction of roads.

To obtain a better understanding of the fuelwood situation in the project area, from June to December 1984 a fuelwood survey was carried out. The objectives of this study were:

- to make an assessment of fuelwood procurement and use by the local people, and 
- to determine, if relevant, the main socio-economic factors restricting the availability of fuelwood.

Methods of investigation. The study consisted of several investigation phases. In the first phase a preliminary census covering all 636 families in the project area was carried out in order to obtain data on family size, income and type of fuel used. In the second phase a more detailed survey was made by interviewing 177 families about their fuelwood procurement and use. In the third phase the cooking habits and actual fuelwood consumption of $\mathbf{1 0}$ families were observed over a period of one week to check consumption data. Another 7 families cooked during one week with supplied fuelwood, in order to measure the fuelwood need under affluent energy conditions. In addition to these observations tests were made with an improved version of the traditional three stone open fire and with two imported stoves, one of metal and one of stone, in order to quantify their saving capacities under local conditions (de Lepeleire et al., 1981; VITA, 1982). For the cooking tests Acacia mollissima fuelwood at a moisture content of $12 \%$ (wet weight base) was used. Further information on various aspects of fuelwood use and procurement was gathered from several key-informants.

Results. Wood appeared to be the most important fuel type in the project area. About $97 \%$ of the households use fuelwood. Cooking is the most important application; fuelwood is hardly used for heating or illumination. Present fuelwood consumption is about $0.9 \mathrm{~kg}$ per person per day. However, by measuring the amounts of fuelwood needed under affluent energy conditions the actual fuelwood need was estimated at $1.5 \mathrm{~kg}$ per person per day. Thus the average family lacks $40 \%$ of its total fuelwood needs. This shortage is covered by preparing less cooked meals and by substituting wood by inferior fuels such as dung and plastic bags.

A possible means to overcome this shortage could be the introduction of more fuel-efficient stoves. However, it was found that both a better fire management by placing protective stones around the open fire and the use of the metal stove would only reduce fuelwood needs by $20 \%$. For the tested stone stove this reduction was even only $15 \%$.

The fuelwood scarcity is not caused by a lack of woody biomass. Rough estimates on the wood production capacity in the forest indicated that these forests are able to supply total future needs for both local consumption and external demand. Rather, the fuelwood scarcity is caused by restrictions in the fuelwood procurement.

More than $90 \%$ of all households obtain fuelwood by collecting it themselves. Only about $16 \%$ of the households buy fuelwood once in a while. This commercial procurement involves only $3 \%$ of the total local needs and $5 \%$ of the consumption. Most of the fuelwood is collected from shrubs growing on the rangelands. In addition, less than $2 \%$ is collected from private agricultural lands, partly because under the traditional land tenure system tenants do not have rights to trees growing on rented land. The Land Reform Act of 1983 is supposed to have changed this situation, but the execution of this law is behind schedule.

Local households hardly obtain fuelwood from State forests, because present Fo- 
rest Laws prohibit any use of threes without permission of MDR. This restriction actually prevents local people from using forests for subsistence fuelwood collection. Fuelwood harvesting in the forests may only be carried out by the Forest Service. The produce is marketed, but the local population is too poor to buy. To satisfy its total fuelwood needs from the market, an average household would have to spend $20 \%$ of its income. Therefore, most of the fuelwood produced by the Forest Service is sold to inhabitants of the cities and to richer farmers in the lower valleys, where the standard of living is considerably higher than in the project area. Here fuelwood is not only used for household purposes, but also in commercial bakeries.

Thus the existing Forest Law and the land tenure system in combination with economic factors prevent local farmers from obtaining sufficient amounts of fuelwood to satisfy their needs. Recently the situation even worsened, because the State has claimed control over the rangelands, which are to be reforested for soil conservation and water-shed management purposes. Consequently, the area of rangelands, where it is possible to gather fuelwood, has decreased.

Conclusion. The Planalto Leste project faces conflicting objectives. The extension of the forest area in order to combat erosion and stimulate water infiltration, results in an increasing shortage of fuelwood for the local population. The introduction of improved cooking devices or other fuelwood-saving techniques may reduce the effects of fuelwood shortages, but will not solve the fuelwood problem in Planalto Leste, since the restrictive external conditions are not properly addressed. The Forest Law should be changed and the Land Reform Act.executed in order to enable people to grow their own fuelwood. In addition, the forest policy has to change and the priorities between the various objectives of afforestation have to be re-assessed. Possible options could be the lowering of fuelwood prices or the preservation of rangelands for fuelwood production systems managed by the local population.

\section{References}

DGIS, 1983. Cape Verde Santo Antäo Rural Development (phase 4). Formulation Report. Wageningen, Netherlands, $50 \mathrm{pp}$.

Lepeleire, G. de et al., 1981. A Woodstove Compendium. Woodburning Stove Group, Technical University, Eindhoven, Netherlands, $379 \mathrm{pp}$.

VITA, 1982. Testing the Efficiency of Woodburning Cook Stoves (preliminary edition). Arlington, USA.

This synopsis is based on an undergraduate thesis entitled 'Brandhout: een kopzorg', Department of Forest Management, Agricultural University, Wageningen, 1985. 119 pp., 16 figs., 19 tables, 40 refs., 10 appendices. Dutch.

Available as paper copy (order R066P, $f 30$ including postage) or microfiches (order R066M, $f 17.50$ including postage) at: NARD, clo Pudoc, P.O. Box 4, 6700 AA Wageningen, Netherlands (telex 45015 blhwg). 